\title{
A HISTORY OF RECENT INFESTATIONS OF THE SPRUCE BUDWORM IN NORTHWESTERN ONTARIO, AND AN ESTIMATE OF RESULTANT TIMBER LOSSES ${ }^{1,2}$
}

\author{
By KEN R. ELLIOTT ${ }^{3}$
}

Kenneth Roland Elliott was born in Peterborough, Ontario in 1922, served in the R.C.A.F. from 1942 to 1946 , received a B.SC. (Forestry) degree from the University of Toronto in 1951 and an M.Sc. (Zoology) degree from the University of Western Ontario in 1954. He joined the staff of the Forest Insect Laboratory in 1951, worked on aerial spray projects and population studies in connection with the spruce budworm and black-headed budworm problems until 1958, and then was transferred from research to administrative work.

\section{ABSTRACT}

The build-up and course of severe infestations of the spruce budworm in the Lac Seul and Lake Nipigon regions of northwestern Ontario is traced from recorded data between 1937 and 1955; the forest cover of the areas is described in general terms; and it is estimated that some 17 million cords of pulpwood were destroyed. The methods employed in this study allow deductions to be made which indicate that the first severe defoliation within the epicenters of the infestations probably occurred in 1939 in the Lac Seul region and in 1937 or 1938 in the Lake Nipigon region; that expansion beyond the epicenters did not occur until the mortality of balsam fir had commenced; and that the increase of the budworm population to the infestation level occurred abruptly. It is also shown that the relatively small and scattered representation of the primary hosts gave no protection from severe damage, and that the potential for future losses within the areas affected by 1955 is almost double the amount destroyed.

\section{INTRODUCTION}

An infestation of the spruce budworm, Choristoneura fumiferana (Clem.), expands rapidly year after year until it is difficult for one to visualize the enormous areas of forested land and volumes of timber that become involved. The estimated $250,000,000$ cords of spruce and balsam that fell prey to the budworm in eastern Canada between 1909 and 1946, was dramatically visualized by de Gryse (8) as the equivalent of a band of pulpwood, 4 feet by 60 feet, completely encircling the earth at the equator. The recognition that such tremendous losses represent a serious threat to the future of the forest industries concerned gave impetus to a rapid post-war expansion of research in forest entomology to gain fundamental knowledge of the factors governing outbreaks (26), and to large-scale aerial-spraying operations that were carried out to curb current losses (2).

The basic information required before research or control projects can be carried out is currently provided in Canada by the Forest Insect and Disease

\footnotetext{
Contribution No. 584, Forest Biology Division, Research Branch, Department of Agriculture, Ottawa, Canada.

${ }^{2}$ Cost of publication shared by Forest Biology Division and C.I.F.

Forest Insect Laboratory, Sault Ste. Marie, Ontario.
} 
Survey, Canada, Department of Agriculture. Insect conditions are determined by means of ground and aerial surveys (usually in co-operation with Provincial air services) for all the major forest districts by a large staff of forest biology rangers and research officers, and by co-operators employed by other government and commercial agencies concerned with forestry or forest operations. Before the Forest Insect Survey was organized in 1936, records of spruce budworm infestations were incomplete because the personnel and facilities required to survey the enormous areas involved were lacking $(25,32)$. During the first eight years of the Survey, the field aspects were carried out almost entirely by co-operators, but with the rapid post-war expansion of personnel and facilities (24), increasingly accurate accounts of infestations were obtained. Until the present time however, no attempt has been made to prepare the history of any one infestation from the separate yearly reports, and the lack of sufficient forest inventory data has prevented the compilation of accurate estimates of the losses (25).

This paper deals with the recent spruce budworm infestations that arose in, and were named for, the Lac Seul and Lake Nipigon areas of northwestern Ontario from their first discovery up to and including 1955.

The forests of northwestern Ontario have suffered spruce budworm infestations in the past. Evidence from suppression patterns in the annual rings of old-age white spruce indicates that a severe infestation was active in the Lac Seul area about 1862-1872 over much of the same area as that affected by the current infestation (4). Similar evidence indicates that the entire Lake Nipigon basin was affected about $1800-1810$ and that a more restricted area southwest of Lake Nipigon was affected about 1880-1890 (personal communicationK. B. Turner, - Ontario Department of Lands and Forests). An infestation in the Lac des Mille Lacs area (about 60 miles west of Port Arthur) was observed in 1925 and 1926 (observed by M. B. Dunn and reported by him in the 1925 and 1926 Annual Reports of the Division of Entomology, Canada Department of Agriculture, Ottawa), and although its duration and boundaries were not determined it was considered to be connected with the series of infestations that affected northern Minnesota from 1912 to 1927 (15, 16).

The historical section of this paper has been prepared mainly from records of insect collections submitted to the Forest Insect Survey, from original records and reports of the forest biology rangers, and from annual technical reports, of the Forest Insect Laboratory, Sault Ste. Marie, Ontario; condensations of the first two have appeared in Annual Reports of the Forest Insect Survey (1936 to 1950) and of the Forest Insect and Disease Survey (1951 to 1955). It represents the work of a great number of workers but individual reference has been made only to those who reported on main events during the course of the infestations. The estimate of timber losses was made possible by the forest resources inventory of the Ontario Department of Lands and Forests that was conducted in co-operation with companies operating on Crown lands between 1949 and 1953 for the areas concerned, and it represents the first instance that such data have been available for an entire infestation area in Canada. In connection with the latter, the author gratefully acknowledges the information and assistance that was freely given by R. M. Dixon and K. B. Turner of the Ontario Department of Lands and Forests, K. W. Hearnden and 
S. T. B. Losee of the Abitibi Power and Paper Company, P. J. Ward of the Great Lakes Paper Company, A. L. K. Switzer of the Longlac Pulp and Paper Company, W. D. Start of the Ontario - Minnesota Pulp and Paper Company, and E. A. Smith of the St. Lawrence Corporation.

\section{Introduction RECORDED HISTORY}

The following account tends to indicate that the forests of northwestern Ontario were largely made up of spruce budworm host trees and that the infestations spread slowly and steadily until practically all of them were damaged or killed as a result of budworm feeding. Such an impression is partially true, because by 1955 the host-trees that occurred within some 20,500,000 acres, or over half of the forested land in the districts of Fort Frances, Kenora, Sioux Lookout, Port Arthur, and Geraldton, had been affected. However, such widespread damage is due mainly to the remarkable power of dispersal that is characteristic of the spruce budworm because, as Table 1 shows, the primary hosts, balsam fir and white spruce, formed a small part of the volume of the forest cover; black spruce formed a comparatively large part but it occurred mainly in pure stands that suffered little or no mortality from budworm attack (26). As described by Halliday (17), the species complex of the forest cover increased from north to south and the northward extensions of the infestations were limited by extensive stands of slow-growing jack pine and black spruce that contained little or no balsam fir. Balsam fir was most commonly associated with white spruce, poplar, and white birch, and such stands were concentrated in the areas where infestations arose. More detailed descriptions of the forest conditions as they existed before host-mortality commenced are included in the historical accounts that follow for each main area of infestation; the placenames and regions referred to are shown in Figure 1.

\section{Early Developments}

The first record of spruce budworm on balsam fir or white spruce in northwestern Ontario was an "enclosure slip" that accompanied a collection submitted to the Forest Insect Survey in 1937 from a point about 40 miles northeast of Kenora. In 1938, collections were submitted from locations near Fort Frances, Kenora, and Port Arthur, and from three more or less evenly distributed locations along the C.P.R. between Kenora and Port Arthur. These same locations were represented in 1939 and 1940 with the addition of a collection from Northern Light Lake ( 80 miles southwest of Port Arthur) in 1939, and of collections from White Otter Lake ( 80 miles northeast of Fort Frances), Wilcox Lake (20 miles west of Lac Seul), Trout Lake, Vermilion Lake (20 miles west of Sioux Lookout), Brennan Lake (midway between Lake St. Joseph and Lake Nipigon), and Gravel Lake (25 miles southeast of Lake Nipigon), in 1940. Records of collections submitted in 1941 are no longer available, but in 1942 budworm collections were submitted from 11 locations along the C.N.R. and C.P.R. lines between the Manitoba boundary and Port Arthur, four locations between Kenora and Fort Frances, three along the Rainy River system between Rainy Lake and Port Arthur, and one each from Vermilion Lake, Birch Lake (20 miles east of Trout Lake), Savant Lake (30 miles south of Lake St. Joseph), Garden Lake (25 miles west of Lake Nipigon), and Pagwachuan Lake (30 miles east of Geraldton). 
TABLE 1

The Per Cent Composition (by Volume and by Species) of Primary Growing Stock (Over 3.6" D.B.H.) on Productive Forest Land IN THE

Forest Districts of NORThWESTERn ONTARIo BEFORE MORTality Resulting From BUdWORM FEeding HAD OCCURRED ${ }^{1}$

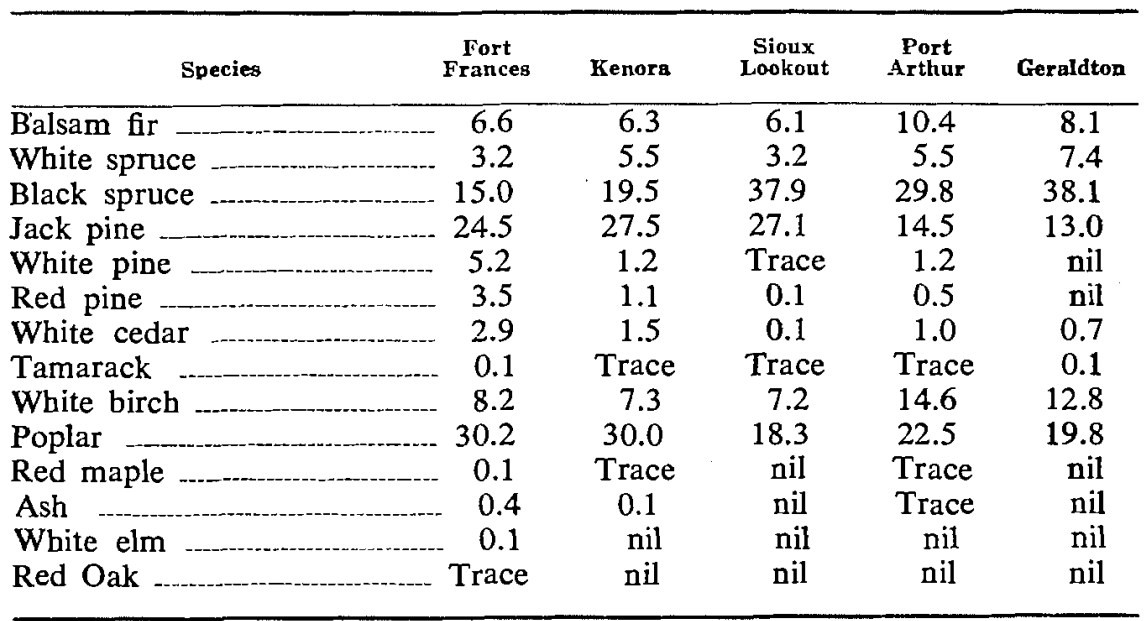

${ }^{1}$ Calculated from gross volume tables of the Forest Resources Inventory (10).

These early reports gave no indication of active infestations or even of noticeable damage, but they did indicate a general build-up of spruce budworm populations throughout northwestern Ontario. However, this warning was obscured by, or confused with, severe infestations of the jack pine budworm that had been active during these years throughout northwestern Ontario and Manitoba (9). Therefore, the discovery of two well-developed infestations of the spruce budworm in 1943 caused much concern as indicated in the first published report by Richmond and Smith (27): "The main areas affected are:(1) Sioux Lookout Region-An extremely active infestation on the peninsula north of Italian Bay on Lost Lake, midway between Sioux Lookout and Hudson, Ontario and (2) Lake Nipigon-Geraldton Region-Infestations of considerable magnitude and of increasing intensity have developed in parts of this latter region and during 1943 reached alarming proportions. The principal infestation on spruce and balsam extends around the south and west sides of Lake Nipigon in the following manner, McDiarmid to Frazer Lake, light; Frazer and Nonwatin Lakes, moderate; Little Sturge and Black Sturgeon Lakes, heavy; Chief Bay, heavy; Chief Bay east, moderate; westward from Lake Nipigon as far as Garden Lake, moderate to light, with diminishing intensity westward. East of Lake Nipigon it is very severe along the Trans-Canada Highway over a ten-mile course immediately southwest of Beardmore, and again heavy 29 miles west of Geraldton extending over a six-mile stretch where young trees are undergoing attack. Over this area, it appears in conjunction with budworm on jack pine. It is moderate in the townsite of Geraldton. In the more easterly portion of this region, it was recorded as light south of White Lake, from where it extends in 
a northeasterly direction as far as the vicinity of Hornepayne. A few records of minor activity of the budworm on balsam fir reveal its presence in such scattered localities as Hawk Lake, near Kenora, and at Pays Plat on Lake Superior. It seems possible that the budworm infestation may cover a considerable portion of this section but that, as yet, it is noticeable only after intensive searching." A reproduction of the infestation map that accompaned this report is shown in Figure 1 along with the infestation maps from the original reports for each year from 1944 to 1955 inclusive; the corresponding acreages of affected forested land (excluding all water, bog, barren, etc., areas) are listed in Table 2 for each of the main infestation areas. The areas of mortality as listed, indicate areas within which host mortality of varying degree had occurred; the assumption was made that any living hosts within these areas were still under heavy-severe attack.

The area to the south, east, and northeast of Lac Seul, within which the Sioux Lookout infestation arose, has a moderately rough, rocky terrain whose thin soils gave support to jack pine and black spruce forests mainly; red and white pine occurred as scattered individuals or in isolated clumps. Concentrations of balsam fir and white spruce, usually in association with poplar and white birch, occurred only in isolated locations in river valleys and on lake shores. Such locations occurred less frequently to the east of the Sioux LookoutHudson area, becoming rare in the area immediately to the west of the Lake Nipigon basin and then increasing in frequency in the river valleys that lead into Lake Nipigon. The concentrations were most extensive in the vicinity of, and to the south and southeast of Chief Bay on the western shore of the Lake where the epicenter of the Lake Nipigon infestation was located (Figure 1-1943 area of heavy-severe defoliation). The lower sites in the river valleys were occupied by black spruce and tamarack and the higher by jack pine, with red and white pine scattered throughout.

Figure 1 and Table 2 show that the Lake Nipigon and Sioux LookoutHudson infestations increased considerably during 1944. In addition, individual collections of the budworm were submitted to the Forest Insect Survey from widely scattered points throughout the remainder of northwestern Ontario. The infestations continued to spread during 1945, but the main event in this year was the discovery of a third center of infestation which was first reported by Prebble (23) as follows: "A notable extension of the spruce budworm outbreak in western Ontario was discovered independently by foresters of the Ontario - Minnesota Pulp and Paper Co., and by forest insect rangers, in late July and early August. This outbreak has been mapped from the air by $S$. Lukinuk and N. R. Brown of the Forest Insect Unit, and comprises approximately 800 square miles in the Sioux Lookout forest district, lying west of Lac Seul, bounded on the north by Pakwash Lake, on the west by Oak Lake and on the south by Maynard and Perrault Lakes. The 1945 defoliation was severe on balsam and white spruce. With the exception of a central area south of Camping Lake where the infestation is evidently of older standing the population increases to outbreak proportions occurred at the time of the 1944 budworm moth flight. A heavy deposition of eggs occurred during the 1945 flight, and an intensification of defoliation injury is anticipated in 1946. The surrounding forest is of such composition to permit enlargement of the area of severe 
TABLE 2

The Yearly Progress of the Lac Seul and Lake Nipigon Spruce Budworm Infestation By Acreage of Forested Land Within Which Defollation and Mortality of Host Trees Occurred

\begin{tabular}{|c|c|c|c|c|c|c|}
\hline \multirow{2}{*}{$\begin{array}{c}\text { Area } \\
\text { and } \\
\text { Year }\end{array}$} & & \multicolumn{2}{|c|}{ Defoliation ${ }^{1}$} & \multicolumn{2}{|c|}{ Mortality 1} & \multirow{2}{*}{$\begin{array}{c}\text { TOTAL } \\
\text { Defoliation } \\
\text { and } \\
\text { Mortality }\end{array}$} \\
\hline & & $\begin{array}{l}\text { Light- } \\
\text { Medium }\end{array}$ & $\begin{array}{l}\text { Heavy- } \\
\text { Severe }\end{array}$ & $\begin{array}{c}\text { Light- } \\
\text { Medium }\end{array}$ & $\begin{array}{l}\text { Heavy- } \\
\text { Severe }\end{array}$ & \\
\hline & & \multicolumn{5}{|c|}{ (Area of defoliation and mortality in thousands of acres) } \\
\hline \multicolumn{7}{|c|}{ (2)- } \\
\hline 1943 & & - & 3 & - & - & 3 \\
\hline 1944 & & - & 30 & - & - & 30 \\
\hline 1945 & & 28 & 411 & - & $\ldots$ & 439 \\
\hline 1946 & & 93 & 729 & - & 46 & 868 \\
\hline 1947 & & 75 & 921 & - & 98 & 1,094 \\
\hline 1948 & $\ldots$ & 393 & 1,388 & - & 145 & 1,926 \\
\hline 1949 & & 70 & 1,725 & - & 257 & 2,052 \\
\hline 1950 & & - & 2,202 & - & 453 & 2,655 \\
\hline 1951 & & 136 & 2,665 & - & 467 & 3,268 \\
\hline 1952 & & 75 & 5,974 & 一 & 1,019 & 7,068 \\
\hline 1953 & & - & 7,311 & - & 1,141 & 8,452 \\
\hline 1954 & 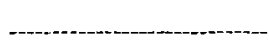 & - & 8,508 & 84 & 1,384 & 9,976 \\
\hline 1955 & - & - & 9,122 & 841 & 1,985 & 11,948 \\
\hline \multicolumn{7}{|c|}{ Lake Nipigon } \\
\hline 1943 & & 2,108 & 243 & - & - & 2,351 \\
\hline 1944 & & 850 & 3,628 & 一 & - & 4,478 \\
\hline 1945 & & 1,153 & 4,403 & - & 一 & 5,196 \\
\hline 1946 & & 1,549 & 4,157 & 572 & 127 & 6,405 \\
\hline 1947 & & 1,341 & 5,612 & 321 & 435 & 7,709 \\
\hline 1948 & & 1,058 & 6,532 & 425 & 510 & 8,525 \\
\hline 1949 & & 19 & 368 & 2,220 & 2,126 & 4,733 \\
\hline 1950 & & 220 & 132 & 2,716 & 2,310 & 5,378 \\
\hline 1951 & - & 一 & 123 & 2,702 & 2,456 & 5,281 \\
\hline 1952 & 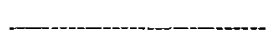 & 151 & 132 & 2,131 & 3,042 & 5,456 \\
\hline 1953 & - & 246 & 283 & 2,130 & 3,042 & 5,701 \\
\hline 1954 & 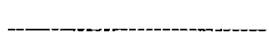 & 406 & 283 & 2,220 & 3,047 & 5,956 \\
\hline 1955 & 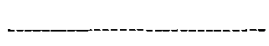 & 76 & 354 & 2,173 & 3,117 & 5,720 \\
\hline
\end{tabular}

"The terms "defoliation" and "mortality" denote the loss of the current year's foliage and the volume dead respectively in classes of Light ( 1 to $20 \%$ ), Medium (21 to $50 \%$ ), Heavy (51 to $80 \%$ ) and Severe (81 to $100 \%)$, based on the observed condition of balsam fir only.

infestation." In a personal communication that referred to the central portion of the infestation and also to the Sioux Lookout - Hudson infestation, W. D. Start, Forestry Supervisor, Ontario - Minnesota Pulp and Paper Co., stated in part: "In 1945, Donald Robb, forester with our company, made a reconnaissance of the Patricia Concession following the canoe routes. Around the shores of Wine, and parts of Wabaskang Lake, he reported a desolate picture of balsam fir and white spruce, dead and dying, from spruce budworm attack . . . During 
the winter of 1944-45 I visited part of the infestation area north of Hudson on Indian Reserve 28 and the balsam were dead but whole, age 30-40 years as well as older."

The area within which the Lac Seul infestation arose (Figure 1-1945) is in that section of the English River drainage system characterized by the heavy clay and sand deposits of glacial Lake Agassiz. The predominant cover consisted of associations of poplar, balsam fir, white spruce and white birch with balsam fir occurring occasionally in pure stands. Black spruce and tamarack occupied shallow swamp areas and jack pine the higher sandy areas. White and red pine had a scattered representation, and black ash, white elm and bur oak were found occasionally.

\section{Development of the Lac Seul Infestation, 1946-55}

The Lac Seul infestation expanded rapidly after its discovery in 1945, but the Sioux Lookout-Hudson infestation remained within a relatively confined area. The reports of these infestations indicate that host-mortality had begun when the infestations were discovered, but as shown in Figure 1, the areas within which mortality had occurred were not mapped accurately until 1946. Records of the Forest Insect Survey indicate that populations of the budworm increased steadily between 1940 and 1949 in the area to the southwest of the main infestation. During the latter year a small pocket of heavy infestation was reported on Cliff Island in Lake-of-the-Woods, and in 1950 the northeast shore and islands of Lake-of-the-Woods between Kenora and Sioux Narrows were heavily infested (22). As shown in Figure 1, this infestation expanded rapidly during 1951 . In 1952, McGugan et al. (21) reported: "In the Northwestern Region, the three infestations formerly referred to as the Lac Seul, Hudson, and Lake of the Woods infestations merged in 1952 and spread southward to include a total area of approximately 12,000 square miles. This area of heavy infestation, roughly halved by the Kenora-Sioux Lookout district boundary, extended between Ball and Honeywell townships in the north, south to a line drawn from the tip of the Alneau Peninsula in Lake of the Woods to Snowden Lake in the east. Egg surveys carried out in the fall of 1952 indicate a continuation of high populations in essentially the same area in 1953." The combined infestation continued to expand with unabated intensity during 1953 and $1954(28,29)$ and its status in 1955 was described by Elliott $(11)$ as follows: "The spruce budworm infestation which has been active in the western forest region of Ontario for at least 15 years, made advances to the south and west in 1955 that carried it out of the Province for the first time and a considerable extension was also made within the Province to the east. To the south, the infestation advanced about 25 miles across the Fort Frances District and was observed in the State of Minnesota along a 70-mile front east of the City of Fort Frances. In the Kenora District, it moved 10 to 15 miles westward to cross the Manitoba border at two points: along a 15-mile front west of the Lake of the Woods and along a 20-mile front centered on Boundary Lake. In the Sioux Lookout District, it advanced to the east about 20 miles to include the area around Sturgeon and Mattawa Lakes, and to the north, as far as existing host stands will allow so that the boundary lies about 20 miles north of Red Lake, as it was in 1954. The advances described above represent a total area 
of approximately 3,500 square miles within which the balsam fir and white spruce stands were heavily defoliated for the first time in 1955."

The extensions of the Lac Seul infestation to the north of the epicenter affected extensive old-burn areas where jack pine predominated and black spruce was prevalent. Balsam fir, usually associated with white spruce, poplar, and white birch, occurred only on suitable sites such as river valleys and lakeshores. To the south of the epicenter the terrain is very irregular with numerous rocky-shored lakes and thin soils. Red and white pine associations were the dominant cover in the past but the effect of fire had been to replace most of these with jack or poplar associations. Balsam fir and white spruce were general throughout with a few scattered concentrations in the northern parts, particularly in the Lake-of-the-Woods area. Black spruce and tamarack occupied swampy areas, and in the southern parts, yellow birch, sugar maple, red maple, black ash, green ash, white elm, and red ash had a scattered representation.

\section{Development of the Lake Nipigon Infestation 1944-1955}

The Lake Nipigon Infestation expanded steadily from its discovery in 1943 until 1948, and during this period an increasing number of collections were submitted to the Forest Insect Survey from the immediate areas to the east and north of Port Arthur and along the C.P.R. as far east as Schreiber. In 1946, heavy defoliation was reported on Pie Island to the northeast of Port Arthur (5), and in 1947 collections were obtained from Sibley Peninsula that indicated high budworm populations. The main infestation reached its maximum size in 1948 when new areas of heavy defoliation were discovered to the south of the main area on Sibley and Black Bay peninsulas and between Gurney and Pays Plat on the north shore of Lake Superior (6). Sharply reduced populations of the budworm within the main infestation area were reported towards the end of the 1948 season (12), and in 1949 McGugan and MacDonald (18) reported: "The Lake Nipigon infestation, which has been exceedingly active during the past six or seven years, has shown a marked decline in practically all areas which have been examined, including the northern section in the Sioux Lookout District, the southern and western sections in the Port Arthur District, and the eastern section in the Geraldton District. The decline in budworm population has, in general, been followed by improved vigour of balsam fir and white spruce to the extent that infestations can no longer be mapped from the air. However, the area over which trees are dying shows a considerable increase both east and west of Lake Nipigon as a result of injury in earlier years. Comparatively small, though active, infestations persist at Sturge Lake, on Sibley Peninsula, on Black Bay Peninsula, and in the vicinity of Gurney near Lake Superior in the Geraldton District." The westward extension of the "Algoma" infestation of northeastern Ontario that had extended to within 15 miles of the Lake Nipigon infestation during 1947 and 1948 (Figure 1), had also collapsed by 1949 (19). The budworm did not disappear entirely from the main Lake Nipigon infestation area because records of the Forest Insect Survey show that collections were submitted from representative points throughout the area of decline from 1949 to 1955 inclusive. Mortalityplot records also show that host mortality continued for several years after the infestation subsided. The heavy infestation that persisted in the southern border 
area of the main infestation after the 1949 collapse was reduced to some 30,000 acres of medium infestation by 1951 (20). However, in 1952 it increased in intensity and heavy defoliation was reported in the Sturge-Disraeli-Little Sturge Lakes area (21). Here it continued to increase in both intensity and area during 1953 and $1954(28,29)$, and then declined in 1955 (11). The infestation on Sibley and Black Bay peninsulas progressed steadily from the time of its discovery in 1948 and was still active in 1955, but the intensity of the infestation in the Gurney-Pays Plat area declined from heavy in 1948 (6) to extremely light in 1951 and then increased to heavy in 1952 (21). In 1953, it enlarged to the east and a band of medium infestation extended westward to join a band of medium infestation that extended northward from the Sibley - Black Bay infestation area (28). The combined infestation continued to increase in both area and intensity during 1954 and 1955 (28, 29). Infestations in the Lake Nipigon area in 1955 were described by Elliott (11) as follows: "The budworm populations in the 50-square-mile remnant south of Black Sturgeon Lake in the Port Arthur District were greatly reduced by increased host mortality but new heavy defoliation occurred within some 4 square miles west of Leckie Lake on the southwestern border of the area. Mortality increased on Sibley and Black Bay peninsulas, but heavy defoliation persisted as it did along the northern shore of Nipigon Bay east to Rossport and North to Greenhedge Lake in the Geraldton District. This infestation affects some 1,100 square miles and new heavy defoliation occurred within an additional 100 square miles north of Greenhedge Lake. New heavy defoliation was also found within some 70 square miles in Bell Township on the eastern border of the District."

The northward and eastward extensions of the infestation beyond the Lake Nipigon basin affected the relatively level, plateau-like country sloping to James Bay that is characterized by extensive sand and gravel deposits, low rocky outcrops, and shallow depressions. Balsam fir and white spruce occurred only on favourable sites such as river banks and lakeshores. Jack pine was dominant, black spruce was prevalent, and poplar and white birch were general throughout. The areas to the south and southeast of the basin are characterized by a rough and irregular terrain with wide river valleys that extend northward from Lake Superior. Lacustrine deposits from glacial Lake Algonquin occur extensively in these valleys and mixtures of balsam fir, white spruce, poplar and white birch, with black spruce added in the lower sites, were common. Jack pine associations occupied the higher and more rocky elevations and black spruce with tamarack, the lower depressions. White cedar was common throughout, and red and white pine had a scattered representation. On Sibley and Black Bay peninsulas where the southern portion of the infestation originated (Figure 1-1948), second-growth balsam fir, white spruce, and poplar occurred extensively, but jack pine and black spruce were the predominant species. White birch was general throughout, and red and white pine occurred as scattered individuals or in isolated clumps.

A numerical summary of the areas affected by the Lac Seul and Lake Nipigon infestations up to and including 1955, is presented in Table 3 ; the forested area affected by the infestations and the portion within which host mortality had occurred, is compared with the total and forested land area of each of the forest districts involved. 
TABLE 3

The Forested Area Affected by the Lac Seul and Lake Nipigon Infestations and the Portion Within Which Host MORTality OCcurRed UP TO AND INCLUding 1955, In COMPARISON WITH THE TOTAL AND Forested Areas of the Forest Districts of Northwestern Ontario

\begin{tabular}{|c|c|c|c|c|}
\hline \multirow[b]{2}{*}{ Area } & \multicolumn{4}{|c|}{ Forest District Affected by the Lac Seul Infestation } \\
\hline & Fort Frances & Kenora & Siollx Lookout & Total \\
\hline \multicolumn{5}{|c|}{$\begin{array}{l}\text { in thox } \\
7772\end{array}$} \\
\hline Total $^{1}$ & 4,490 & 7,772 & 13,800 & 26,062 \\
\hline Forested Land ${ }^{2}$ & 3,058 & 5,209 & 10,915 & 19,182 \\
\hline Infestation ${ }^{3}$ & 1,623 & 4,524 & 5,802 & 11,948 \\
\hline \multirow[t]{3}{*}{ Host Mortality ${ }^{4}$} & nil & 195 & 2,631 & 2,826 \\
\hline & \multicolumn{4}{|l|}{ Forest Districts } \\
\hline & Port Arthur & Geraldton & Sionx Lookout ${ }^{0}$ & Total \\
\hline Total $^{1}$ & 10,811 & 7,885 & 4,293 & 22,989 \\
\hline Forested Land ${ }^{3}$ & 7,909 & 6,262 & 3,567 & 17,738 \\
\hline Infestation ${ }^{3}$ & 3,557 & 3,969 & 1,000 & 8,526 \\
\hline Host Mortality & 2,976 & 1,456 & 859 & 5,291 \\
\hline
\end{tabular}

${ }^{3}$ Includes all land types and water areas.

${ }^{2}$ All land producing or capable of producing commercial timber.

${ }^{3}$ The maximum area of forested land within which host trees had been affected.

"That portion of the "infestation area" within which host trees had been killed.

"That part of the district lying west of Longitude $90^{\circ} 15^{\prime} \mathrm{W}$ and north to Latitude $51^{\circ} 22^{\prime}$ $30^{\prime \prime} \mathrm{N}$.

'That part of the district lying east of Longitude $90^{\circ} 15^{\prime} \mathrm{W}$ and north to Latitude $51^{\circ} \mathrm{N}$.

TIMBER LOSSES

Timber losses are expressed here as the net merchantable (NM) volumes of balsam fir, white spruce, and black spruce that were killed by the spruce budworm and resultant agencies during the recent infestations in northwestern Ontario. No attempt has been made to evaluate losses incurred by reduced increment, dead terminal, or other damage in surviving trees, nor the effect of host-mortality upon site or forest composition. The losses have been calculated by first dividing the 1955 host-mortality areas into "damage zones" on the basis of the number of years of continuous defoliation required to cause light, medium, heavy, and severe mortality of balsam fir (see footnote 1, Table 2 for defoliation and mortality classes); the average per cent mortality for each host-species, as determined from mortality-plot data, was then applied to the respective NM volumes within each zone to obtain the volumes dead. The methods used and the results obtained are presented below:

Host-mortality data, on a per cent volume basis, were available from the records of the Forest Insect Laboratory for 23 plots in each of the two main infestation areas. In the Lac Seul area, nine permanent plots were established in 1946, four in 1949, and one in 1952; all were tallied yearly up to and including 1955. In addition, nine temporary plots were established in 1947 and were tallied in 1948 and 1949 only. In the Lake Nipigon area, 11 permanent plots were established in 1943, nine in 1944, one in 1952 and two in 1953; all were tallied yearly up to and including 1955. The plots had a minimum size of 0.2 acres and were established in stands of high balsam fir content. As a result of the latter, only 10 plots in the Lac Seul area and 11 in the Lake Nipigon 
FIGURE 1. The yearly extent and intensity of spruce budworm infestations in the Lac Seui and Lake Nipigon areas of northwestern Ontario as reported in original records of the Forest Insect Laboratory, Sault Ste. Marie. 
area contained significant yolumes of white and black spruce for the calculation of per cent mortality of these species. Where the total volume for either species was represented by 10 trees or less, the data were rejected because the death of any one tree, especially one of high volume, presented a distorted picture of per cent mortality.

The relatively small number of host-mortality plots necessitated a grouping that would represent average conditions. Data from all plots where the defoliation history was known were first arranged in order of the number of years of defoliation, rather than in chronological order, and the number of years of defoliation required to cause light (1-20\%), medium (21-50\%), heavy $(51-80 \%)$, and severe $(81-100 \%)$ mortality of balsam fir was then calculated by placing the average mortality for consecutive years of defoliation within these classes. Only heavy to severe defoliation was considered and data obtained from areas where defoliation had ceased (main Lake Nipigon infestation area after 1949) were omitted. Where plots were established before mortality due to budworm feeding could possibly have commenced, trees recorded as dead on the first year's tally were deleted. Balsam fir was used as the standard because it was well represented in all of the plots, whereas white and black spruce were not. This is illustrated by the even distribution of the average mortality points for balsam fir and the uneven distribution of those for white and black spruce in the freehand curves of Figure 2 which show the relationship between continuous defoliation and host-mortality. The number of years of defoliation as shown in this figure refers to the number of years required to cause the mortality, i.e., the mortality indicated for 5 years of defoliation was recorded in the 6th year. The corresponding number of years required to cause light, medium, heavy, and severe mortality of balsam fir is listed in the left-hand columns of Table 4. These limits were used to define the "damage zones" illustrated in Figure 3 that were determined by superimposing on each other the defoliation maps for consecutive years. The average mortality that had occurred within the zones by 1955 was calculated from the 1955 data for all host-mortality plots within each zone and the results are listed in the righthand columns of Table 4. Attention is drawn to the 1955 averages for the Lake Nipigon area. They do not coincide with the curves in Figure 2 and are higher than those for the Lac Seul area; also, a "light zone" was not delineated and the average for balsam fir in the medium zone exceeds the arbitrary limit of 50 per cent. These apparent discrepancies reflect the mortality of weakened trees that occurred after the infestation declined in 1949; defoliation also ceased after this date so that such host mortality was not considered when the effect of continuous defoliation was calculated. This situation was not encountered in calculations for the Lac Seul area because defoliation there was continuous.

The forested areas and the volumes of balsam fir, white and black spruce required to calculate the extent and amount of the damage were calculated from original records of the Forest Resources Inventory, Ontario Department of Lands and Forests (FRI). The FRI employed two basic units; the base map which represents $1 / 32$ of the area enclosed within one degree of latitude and longitude, and areas under license to pulp and paper companies. Each unitarea was classified by FRI into forested and non-forested (water, bog, barren, etc.,) areas; the forested area was subdivided (on an acreage basis) into three cover types (coniferous, hardwoods and mixedwoods) with two age classes 
(mature and immature), two diameter classes (4 to 9 inch, and 10 inch and up) and four density classes (full, normal, medium and open stocking). Corresponding volume tables (cubic foot per acre), which varied according to the ecological section involved, were applied to the base-map units to obtain the gross volumes of balsam fir, white spruce, and black spruce. For units under license to companies, the volumes had been computed previously on the foregoing basis. The total and forested areas and volumes for each infestation area, mortality area, and mortality zone, were calculated by summing the respective totals from all full and partial units that occurred within the areas concerned. The assumption was made that the components of a unit were evenly distributed and the portion required for partial units was calculated as a simple fraction of the total; a planimeter was used to determine the fraction. The volume figures thus obtained represent the volumes present when the inventories were com-



FIGURE 2. The effect of continuous defoliation on the host-mortality rate as indicated by the number of previous years of heavy to severe defoliation required to cause light, medium, heavy and severe mortality of balsam fir. 
pleted (in all cases before host mortality commenced) and not the volumes present in 1955. To correct for this, the assumption was made that there would be no significant increase due to yearly increment when the infestations were active. Deductions were then made for volumes removed by fire or by cutting operations (both normal and salvage) after the inventories were completed. Further deductions were made for black spruce within host-mortality areas only. This species suffers little or no mortality when growing in pure stands (26) and the portion of the volume included in coniferous types was considered to be "non-susceptible" and was deducted. The revised totals were converted to cords on the basis of 85 cubic feet per cord, and to net merchantable volumes by the use of cull factors applicable to northwestern Ontario: 0.83 and 0.78 for white and black spruce, and 0.58 and 0.56 for balsam fir in the 4 to 9 inch, and

TABLE 4

The Number of Years of Continuous Defoliation Required to Cause light, Medium, Heavy and Severe Mortality of Balsam Fir and the Average Per Cent Mortality of Host-Species in Each Damage Zone IN 1955

\begin{tabular}{|c|c|c|c|c|c|c|c|c|}
\hline \multirow{3}{*}{$\begin{array}{l}\text { Zones } \\
\text { Damage }\end{array}$} & \multirow{2}{*}{\multicolumn{2}{|c|}{$\begin{array}{l}\text { Number of Years of } \\
\text { Continuous Defoliation }\end{array}$}} & \multicolumn{6}{|c|}{ A verage Per Cent Mortality in 1955} \\
\hline & & & \multicolumn{3}{|c|}{ Lac Scul Area } & \multicolumn{3}{|c|}{ Lake Nipigon Area } \\
\hline & Lac Seul & $\overline{\text { Lake Nipigon }}$ & $\overline{\mathbf{b F}}$ & $\mathbf{w S}$ & bS & $\mathbf{b F}$ & wS & bS \\
\hline Light & 4 to 6 & 4 to 5 & 14 & 9 & 2 & - & - & - \\
\hline Medium & 7 & 0 & 43 & 31 & 18 & 54 & 42 & 21 \\
\hline Heavy & 8 & 7 to 8 & 66 & 40 & 26 & 78 & 64 & 43 \\
\hline Severe & $9+$ & $9+$ & 100 & 70 & 51 & 100 & 79 & 64 \\
\hline
\end{tabular}

See Figure 3.

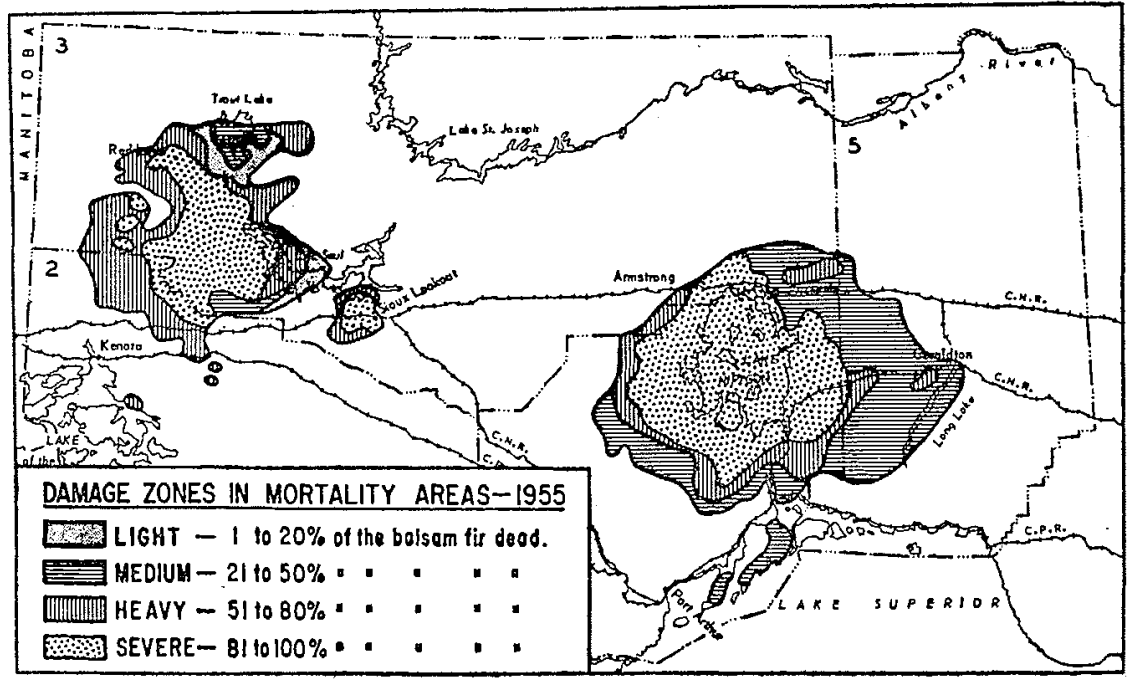

FIGURE 3. Division of the 1955 host-mortality areas into damage zones as indicated by the relationship berween number of years of defoliation and average per cent mortality. 
TABLE 5

The Forested Area of Damage Zones Within Mortality Areas, the Net Merchantable Volumes of Host-Species and the Portion Dead Within EACH ZONE IN 1955

\begin{tabular}{|c|c|c|c|c|c|c|c|}
\hline \multirow[b]{2}{*}{ Damage Zones ${ }^{2}$} & \multirow[b]{2}{*}{ Acre: } & \multicolumn{3}{|c|}{ Zones } & \multicolumn{3}{|c|}{ Volume Dead in 1955} \\
\hline & & $\mathbf{b F}$ & WS & bS & $\mathbf{b F}$ & $\mathrm{wS}$ & $\mathrm{bS}$ \\
\hline Lac Seul Area & & \multicolumn{6}{|c|}{ (Volume in thousands of cords) } \\
\hline ight & 379 & 384 & 334 & 387 & 54 & 30 & 8 \\
\hline Medium & 462 & 466 & 406 & 47 & 200 & 12 & 85 \\
\hline eavy & 662 & 673 & 5 & 67 & 444 & 23 & 176 \\
\hline vere & 1,323 & 1,339 & 1,165 & & ,339 & 81 & 689 \\
\hline otal & 2,826 & 862 & 2,490 & 889 & 2,037 & 1,20 & 958 \\
\hline \multicolumn{8}{|l|}{ Lake Nipigon Area } \\
\hline ight & 0 & 0 & 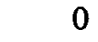 & 0 & 0 & 0 & $\mathbf{0}$ \\
\hline edium & 2,173 & 3,036 & 2,557 & 376 & 1,639 & 1,074 & 709 \\
\hline eavy & 741 & 1,034 & 871 & 1,450 & 807 & 557 & 495 \\
\hline vere & 2,377 & 3,316 & 2,793 & 3,688 & 3,316 & 2,207 & 2,360 \\
\hline otal & 5,291 & 7,386 & 6,221 & 8,214 & 5,762 & 3,838 & 3,564 \\
\hline Irand Total & 8,117 & 10,248 & 8,711 & 11,103 & 7,799 & 5,044 & 4,522 \\
\hline
\end{tabular}

'See Figure 3.

'The volumes listed for black spruce represent the content of mixed and hardwood stands only. See text and footnote 3, Table 6.

In thousands of acres.

the 10 inch and up, diameter classes respectively. Finally, the volumes dead in 1955 were calculated by applying the 1955 average host mortality for each species to the corrected NM volumes for the respective "damage zones".

The results of these calculations are shown in Table 5 which lists the forested area, total NM volume and NM volume dead in 1955 for each damage zone, and in Table 6 which lists the distribution of the volumes by forest districts and for the entire infestation area within the districts. They show that over $17,000,000 \mathrm{NM}$ cords of pulpwood were destroyed in northwestern Ontario up to and including 1955 . These losses represent some 58 per cent of the host tree volumes within both mortality areas, or 51 per cent in the Lac Seul area and 61 per cent in the Lake Nipigon area. The distribution of these losses as listed in Table 6 show that the potential for future losses (considered here as a direct function of the volumes available within the forest districts involved) is extremely high for the Lac Seul area and low for the Lake Nipigon area.

\section{Discussion}

A general build-up of populations of the spruce budworm in northwestern Ontario from 1937 onwards was indicated by collection records of the Forest Insect Survey, but the original reports of the Lake Nipigon and Sioux LookoutHudson infestations in 1943 and of the Lac Seul infestations in 1945 gave no indication of when the infestations had originated. The epicentre of the Lake Nipigon infestation was located somewhere in the area between Chief and Gull 
TABLE 6

Volumes of Spruce Budworm Host Trees in Northwestern Ontario, 1955

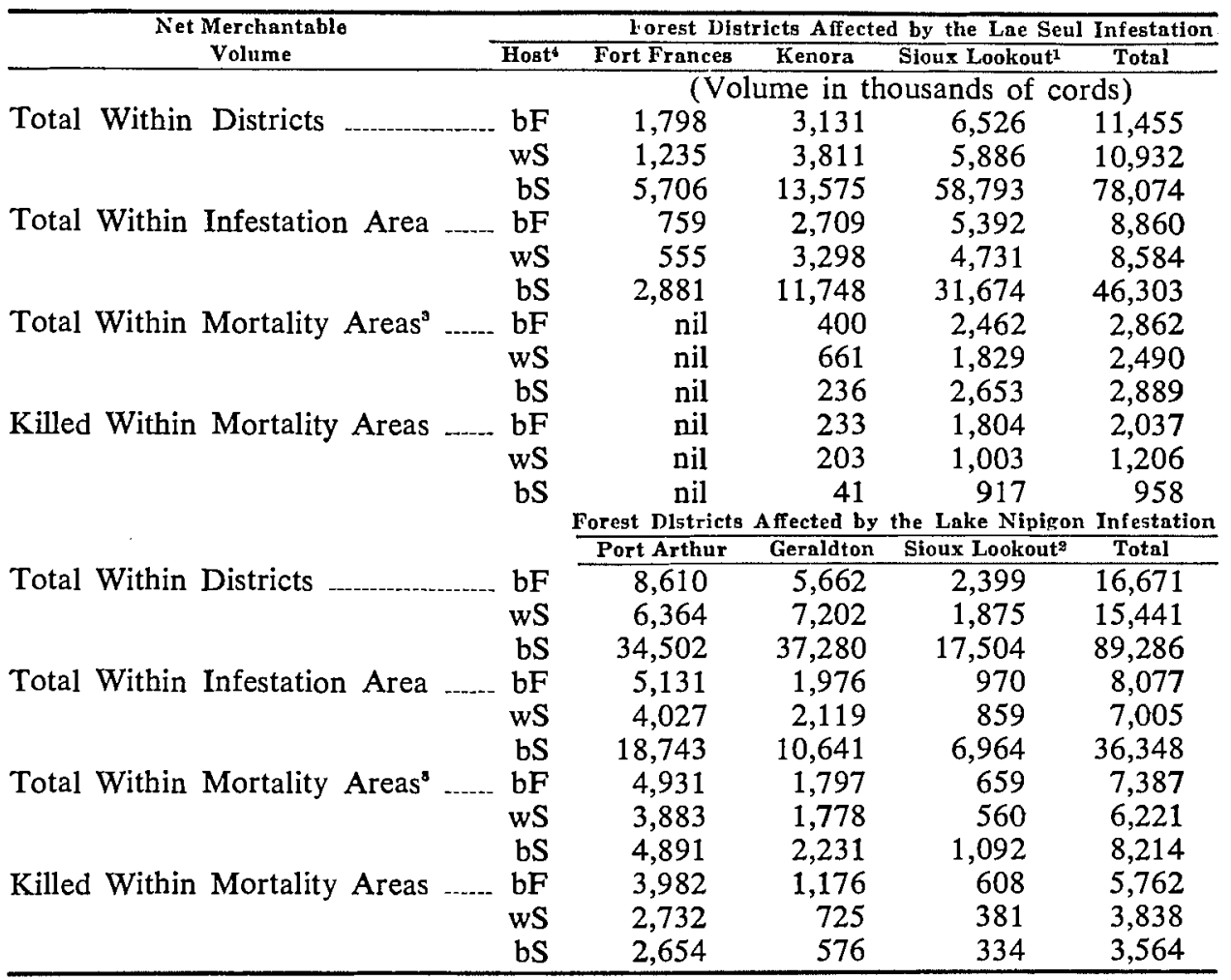

${ }^{1}$ Western portion only, see footnote 5, Table 3 .

${ }^{2}$ Eastern portion only, see footnote 6 , Table 3.

$\mathrm{a}$ The volumes listed for black spruce represent the content of mixed and hardwood types only; in "pure" black spruce stands (which are comparatively immune to severe damage) in the Lac Seul and Lake Nipigon mortality areas there are 10,671,000 and 27,134,000 additional net merchantable cords respectively.

${ }^{\mathrm{bF}}=$ balsam fir; $\mathrm{wS}=$ white spruce; $\mathrm{bS}=$ black spruce.

Bays, and Fettes (13) determined, by the accurate dating and measurement of internodes on the branches of balsam fir, that the first year of severe defoliation occurred in the Chief Bay area at least in 1940 or possibly as early as 1938 . Host-mortality studies carried out in the same area by Belyea (3) showed that mortality of balsam fir began in the fifth year of severe defoliation, and by assuming that mortality began in 1944 , the deduction was made that the first severe defoliation occurred in 1940 . However, data of the host-mortality plots referred to in the present study show that 8,7 and 15 per cent mortality of balsam fir was recorded in one plot in the Chief Bay area and in two plots in the Gull Bay area respectively, when the plots were established in 1943. (These 
percentages were calculated after the volumes of all suppressed trees that were recorded as dead when the plots were established were removed from the data; there was some doubt whether they had died as a result of budworm feeding or as a result of natural competition.). When compared with data of other plots whose full history was known, the foregoing degrees of mortality could not have occurred in the first year of mortality. It is therefore probable that mortality began in 1941, or in 1942 at the latest which, by Belyea's criterion, would place the first occurrence of severe defoliation in 1937 or 1938. These dates were also determined by Ghent (14), on the basis of damage to the shoots and leaders of balsam fir reproduction.

The determination of the effect of continuous defoliation on the host-mortality rate was primarily intended to aid in dividing the areas of host mortality into zones. However, it can also be used to estimate the occurrence of the first year of heavy to severe defoliation if the assumption is made that the average rate of mortality for the host-mortality areas in general was equal to the average rate within the epicentres. This method indicates that 5 and 11 previous years of defoliation were required in the Lake Nipigon area to cause 10 and 100 per cent mortality of balsam fir respectively; the average mortality of balsam fir in the Chief Bay and Gull Bay plots was approximately 10 per cent in 1943 and was 100 per cent in the Chief Bay plot in 1948 and in the Gull Bay plots in 1948 and 1949. On this basis, the first year of heavy to severe defoliation is again deduced to have occurred in 1937 or 1938 . Similarly, the average mortality of balsam fir in three temporary plots (Italian Bay of Lost Lake) within the epicentre of the Sioux Lookout - Hudson infestations was 67 per cent in 1947 and 85 per cent in 1948, and that in four temporary plots near the epicentre of the Lac Seul infestation was 62 per cent in 1947 and 82 per cent in 1948. In both cases, the degrees of mortality reached in 1947 and 1948 would have required 8 and 9 previous years of defoliation, respectively, so that the first heavy to severe defoliation probably occurred in 1939 at the latest for both the Sioux Lookout and Lac Seul infestations.

The infestation maps show that the Lac Seul and Lake Nipigon infestations advanced rapidly year after year and that less spectacular advances were made by the Sioux Lookout - Hudson infestation. However, when the maps are compared with the probable first years of severe defoliation, it becomes apparent that the infestations remained within relatively small epicentres for 4 or 5 years before the first large advances occurred. In the original report of the Lac Seul infestation, Prebble (23) noted that only a small central portion (46,000 acres) of the total infestation area (374,000 acres) had been infested before 1945; also, host-mortality data show that mortality of balsam fir within this epicentre was well advanced in 1945 but it was not until 1950 that mortality was well advanced throughout all the 1945 area of infestation. Mortality of balsam fir had also commenced within the Sioux Lookout - Hudson infestation area when discovery was made. This area was about 3,000 acres in size in 1943; it advanced to 30,000 acres in 1944 and to 65,000 acres in 1945. Advances during the period from 1946 to 1951 were limited; this factor will be discussed later. Similarly, the host-mortality data indicate that the Lake Nipigon infestation did not advance beyond the Gull Bay - Chief Bay epicentre (127,000 acres) until 1942; the size of the total area of infestation was not determined in 1942, 
but it was 2,351,000 acres in 1943. Therefore, in all three cases, the evidence indicates that the first large advances beyond the initial areas of infestation did not occur until mortality of balsam fir had commenced.

Some indication of the length of time required for budworm populations to increase from endemic to epidemic levels is given by the Sibley - Black Bay, Gurney - Pays Plat, and Lake-of-the-Woods infestations that arose after the main infestations had been active for some years. Reports submitted to the Forest Insect Survey show that the budworm was present throughout the general areas where these infestations arose from 10 to 12 years before noticeable damage occurred. In each case, the increase of the population to the infestation level occurred as an eruption rather than as a gradual build-up. Reports of budworm in these areas were first received in 1938 and the number steadily increased during succeeding years; the increase probably reflecting the growing efficiency of the Forest Insect Survey rather than increasing budworm populations, because none of the early reports indicated that noticeable defoliation had occurred. The original report of the Lake Nipigon and Sioux Lookout - Hudson infestation in 1943 (27), noted that the presence of the budworm in such scattered locations as Hawk Lake near Kenora and Pays Plat on Lake Superior was evident only after intensive searching. The first indication of defoliation damage in the Sibley - Black Bay area came from Pie Island, immediately southwest of Sibley Peninsula, in 1946. Collections from Sibley in 1947 indicated that budworm larvae and pupae were numerous in some sections of the peninsula and absent in others, but no mention was made of serious defoliation. However, in 1958, heavy defoliation was general in the central portion of the peninsula and throughout all of Black Bay Peninsula. Also, the 1947 reports from the Gurney - Pays Plat area indicated that budworm larvae were more numerous than in 1946, but serious defoliation throughout any appreciable area did not occur until 1948. Similar reports preceded the Lake-of-the-Woods infestation. Increasing populations were indicated in 1947 but only one small pocket of heavy defoliation was reported in that year; in 1948, heavy defoliation was reported over a widespread area.

The Gurney - Pays Plat and Sibley - Black Bay infestations were considered to be southern extensions of the main Lake Nipigon infestation (6). This consideration was probably correct for the former because it decreased in intensity along with the main infestation and during 1950 and 1951 it could not be mapped from the air. However, in 1952 it increased in intensity, expanded to join the Sibley - Black Bay infestation in 1953, and extended northwards during 1954 and 1955 to reinfest areas that had suffered medium to heavy host mortality from the main infestation. The Sibley - Black Bay infestation did not decline but increased in both area and intensity from 1948 onwards in the manner of an independent infestation. Similarly, the proximity of the Lake-of-the-Woods infestation to the main Lac Seul infestation presented the possibility that it was an extension of the main infestation. However, the records indicate that the eruption originated from the endemic population which had been present in the area for about 12 years.

The infestation maps indicate that the main Lac Seul infestation developed as numerous patches that later coalesced, but the infestation actually developed as a unit, spreading outwards year after year. The mapping was carried out 
from the air by locating the boundary of a defoliation or mortality area and then following it back to the starting point. This process was complicated in part by inherent difficulties such as the decreasing visibility of current defoliation damage during the time required to complete the mapping (from several days to several weeks, depending upon the size of the area and upon the flying conditions), the nonuniformity of damage within stands, and variations in the appearance of the damage due to the number of years of attack; but the main difficulty was caused by the forest composition. As described earlier, balsam fir and white spruce formed a small part of the forest cover and they were not distributed evenly; the host stands were scattered or the hosts occurred as minor components in mixed stands. This was particularly so in the Lac Seul area, because the host stands occurred largely in the main drainage areas which were separated by extensive areas that contained little or no balsam fir and white spruce. Therefore, the tendency was for the observers to map the damage within the areas where the host species were concentrated, rather than map the over-all area within which the damage occurred.

In 1945 , DDT was applied by aircraft to two experimental blocks in the southern border area of the Lake Nipigon infestation: one of about 38 square miles around Circle Lake and the other of about 62 square miles around Little Sturge Lake (7); and to a strip 400 feet wide and some 11 miles long that completely surrounded the area of heavy defoliation in the Sioux LookoutHudson infestation area (1). In 1946, a second aerial spraying experiment was carried out in the vicinity of Eaglehead Lake about 15 miles west of the blocks sprayed in 1945 (31). Post-spray checks in the Little Sturge and Eaglehead areas showed that current defoliation was reduced considerably during the year of the spraying but that the areas were reinfested the year after. Unfortunately, post-spray checks were not made in the Circle or Sioux Lookout areas. This is particularly unfortunate in the case of the Sioux Lookout area because the infestation maps show that the infestation did not advance far beyond the sprayed strip until it was engulfed by the rapidly expanding Lac Seul infestation in 1952. That the surrounding strip of spray prevented further spread during the period 1946 to 1951 seemed highly improbable in view of the reinfestation encountered in the other experimental areas. However, the confinement is only partially explained by the known lack of host stands in the immediate vicinity, because the spread of the Lac Seul infestation was able to affect the closest neighbouring stands which completely surrounded the Sioux Lookout area. Also, after the main Lake Nipigon infestation declined in 1949, a small remnant persisted until 1955 which was roughly within the area sprayed around Little Sturge Lake. The results of a survey carried out in this area by the author in 1954 suggest that the reduction in defoliation due to the 1945 spraying may have allowed an increase in vigour that prolonged the life of the trees. This effect was not uniform throughout the area but it was most noticeable where the spray was most effective. That the increase in tree-vigour actually prolonged the infestation was not proved because ecological conditions within the area did not differ greatly from similar areas where the infestation ceased, but the only known factor that differentiated the remnant area from other areas affected by the main infestation was the DDT spraying project in 1945 .

The main Lake Nipigon infestation declined as a unit, even in the border 
areas where defoliation had occurred for only one to three years and where the supply of host-trees was by no means exhausted. The cause of this decline was not definitely determined.

Despite the complexities of the spruce budworm problem referred to above, the present study shows that during the years immediately preceding 1956, the infestations in nothwestern Ontario were more destructive than would appear probable in consideration of the relatively small and scattered representation of the primary hosts, balsam fir and white spruce. Also, the host mortality and defoliation records, used here to estimate the timber losses, show that the spread of the infestations was not as uniform as suggested by the infestation maps or by the historical account, which of necessity, treat the spread of the infestations in general terms. That mortality of balsam fir began after 4 years of defoliation and was not complete until after 11 years, shows that all the host trees within any one stand did not suffer the same intensity of attack and that individual trees varied in their susceptibility to mortality.

The relative paucity of host-mortality data does not allow an exact accounting of the timber losses, but the methods used permit averaging of the extreme variations that occur within any one of the large zones. The estimate obtained is therefore considered to be as accurate as possible within the limits of the available host-mortality and forest inventory data. The method may also be used to calculate future losses as the degree of damage becomes known.

Losses expressed in terms of net merchantable cords do not necessarily provide the full economic implications of spruce budworm infestations. Salvage operations can reduce the losses and should be economical if carried out before the dead trees deteriorate. Opinions, solicited from operators in northeastern Ontario on the degree of mortality that would render such operations uneconomical, varied from 30 to 80 per cent, which show that partial mortality can in effect cause a 100 per cent economic loss. Therefore, in accessible areas, the estimate of timber losses as expressed here would be low, but in inaccessible areas where harvesting may not take place until a new crop has replaced the dead trees, there would be no apparent economic loss. In 1955, approximately 24 per cent of the forested area in the Lac Seul mortality area was under timber license and could therefore be considered accessible, but the remaining 76 per cent was under Crown ownership and only a small portion of this was accessible by road or railroad. Most of this was expected to be under timber license by 1960. In the Lake Nipigon area in 1955, 83 and 17 per cent of the forested area were under timber license and Crown ownership, respectively. About one half of the latter was accessible by road (Sibley Peninsula) so that about 90 per cent of the entire mortality area was accessible. Therefore, considering the relative accessibility of the two areas, the losses in the Lake Nipigon area are more serious and immediate economically than those in the Lac Seul area. However, such a consideration does not take into account small local areas of high value. In addition, timber losses cause a decrease in the yield per acre and a resultant increase in the cost per acre. For example, access roads must be built through areas of dead timber without the benefit of a harvest from these areas to offset the cost. Other economic factors that are difficult if not impossible to assess, are the loss of increment or the damage to trees that suffer defoliation but escape death, and the effect of tree killing upon the forest com- 
position or upon the site. Because of the foregoing factors, and other related factors, no attempt has been made to estimate the current monetary value of the losses.

\section{REFERENCES}

1. ADDISON, PETER, 1949. Application of DDT in control of the spruce budworm. In Forest spraying and some effects of DDT. Ont. Dept. Lands and Forests, Div. Res., Biol. Bull. 2: $113-140$.

2. BALCH, R. E., F. E. WEBB, and J. J. FETTES, 1956. The use of aircraft in forest insect control. II. Recent spruce budworm operations. For. Abs. 17(1): 3-9.

3. BELYEA, R. M. 1952. Death and deterioration of balsam fir weakened by spruce budworm defoliation in Ontario. II. An assessment of the role of associated insect species in the death of severely weakened trees. J. For. $50(10): 729-738$.

4. BLAIS, J. R. 1954. The recurrence of spruce budworm infestations in the past century in the Lac Seul area of northwestern Ontario. Ecology, 35(1): 62-71.

5. BRADLEY, G. A. and J. E. MACDONALD, 1946. Spruce budworm. Northern Ontario. In Ann. Rept. For. Ins. Surv, Can. Dept. Agr., Ottawa, 1946: 42-44.

6. BRADLEX, G. A. and J. E. MACDONALD, 1948. Spruce budworm. Northern Ontario. In Ann. Rept. For. Ins. Surv., Can. Dept. Agr., Ottawa, 1948: 54-57.

7. BROWN, N. R. 1946. Nipigon spraying operation. In Forest Insect Invest. Bi-monthly Progress Report, Can. Dept. Agr. 2 (1): 1-2.

8. de GRYSE, J. J. 1947. Noxious forest Insects and their control. Reprinted from the Canada Ycar Book.

9. Division of Entomology, 1936 to 1949. Annual Report of the For. Ins. Surv, Can. Dept. Agr., Ottawa.

10. Division of Timber Management, 1953. Forest resources inventory. Ont. Dept. Lands and Forests Reports 5, 6, 14, 15 and 16 .

11. ELLIOTT, K. R. 1955. The status of spruce budworm infestations in the western and midwestern forest regions of Ontario in 1955. Bi-monthly Progress Report. Can. Dept. Agr. $11(5): 1$.

12. FETTES, J. J. 1949. Spruce budworm population trends in a section of the Lake Nipigon infestation. Forest Insect Invest. Bi-monthly Progress Report. Can. Dept. Agr. 5(1): 2.

13. FETTES, J. J. 1950. Investigations of sampling techniques for population studies of the spruce budworm on balsam fir in Ontario. Ph.D. Thesis, University of Toronto.

14. Ghent, A. W. 1958. Mortality of overstory trembling Aspen in the Lake Nipigon forest area of Ontario in relation to recent outbreaks of the forest tent caterpillar and the spruce budworm. Ecology 39(2): 222-232.

15. GRAHAM, S. A. 1923. The dying balsam fir and spruce in Minnesota. Univ. Minn. Agr. Ext. Div. Spec. Bull. 68.

16. GRAHAM, S. A. and L. W. ORR, 1940. The spruce budworm in Minnesota. Univ. Minn, Agr. Expt. Sta. Tech. Bull. 142.

17. HALliDAY, W. E. D. 1937. A forest classification for Canada. Can. Dept. Mines and Resources, For. Serv. Bull. 89.

18. McGUGAN, B. M. and J. E. MacDONALD, 1949. Northern Ontario. Forest Insect Survey, Forest Insect Invest. Bi-monthly Progress Report, Can. Dept. Agr., 5(4): 2.

19. McGUGAN, B. M. and J. E. MacDONALD, 1949. Spruce Budworm. In Ann. Rept. For. Ins. Surv., Can. Dept. Agr., 1949: 48-50.

20. McGUGAN, B. M., W. H. HALIBURTON and J. E. MacDONALD, 1951. Spruce Budworm. In Ann. Rept. For. Ins. and Dis. Surv., Can. Dept. Agr., 1951: 40-41.

21. McGUGAN, B. M., W. H. HALIBURTON and J. E. MacDONALD, 1952. Spruce budworm. In Ann. Rept. For. Ins, and Dis. Surv., Can. Dept. Agr., 1952: 42-43.

22. McGUGAN, B. M., E. B. WATSON and J. E. MacDONALD, 1950. Spruce budworm. In Ann. Rept. For. Ins. Surv., Can. Dept. Agr., 1950: 42-43.

23. PREBBLE, M. L. 1945. Spruce budworm in Ontario. Forest Insect Invest., Bi-monthly Progress Report, Can. Dept. Agr. 1(5): 2. 
24. PREBBLE, M. L. 1946. Forest Insect Survey. Forest Insect Invest. Bi-monthly Progress Report, Can. Dept. Agr. $2(2): 2$.

25. PREBBLE, M. L. 1951. Forest Entomology in relation to silviculture in Canada. I. A review of general principles. For. Chron. 27(1): 1-7.

26. PREBBLE, M. L. 1954. Review of Forest entomology, 1948-1953. Reprinted from the Report of the Sixth Commonwealth Entomological Conference, London.

27. RICHMOND, H. A. and D. N. SMITH, 1943. Spruce budworm in far western Ontario. In Ann. Rept. For. Ins. Surv., Can. Dept. Agr., 1943: 46-47.

28. SIPPELI, W. L., J. E. MacDONALD and D. R. WALLACE, 1953. Spruce budworm. In Ann. Rept. For. Ins. and Dis. Surv., Can. Dept. Agr., 1953: 53-54.

29. SIPPELL, W. L., J. E. MacDONALD and D. R. WALLACE, 1954. Spruce budworm. In Ann. Rept. For. Ins, and Dis. Surv., Can. Dept. Agr., 1954: 47-49.

30. SIPPELL, W. L., J. E. MacDONALD and D. R. WALLACE, 1955. Spruce budworm. In Ann. Rept. For. Ins. and Dis. Surv., Can. Dept. Agr., 1955: 36-37.

31. STEWART, K. E. 1949. Large scale spray operations, Eaglehead Lake, 1946. In Forest spraying and some effects of DDT. Ont. Dept. Lands and Forests, Div. Res. Biol. Bull. 2 : 113-140.

32. SWAINE, J. M. and F. C. CRAIGHEAD, 1924. Studies on the spruce budworm (Cacoecia fumiferana Clem.) I. A general account of the outbreaks, injury and associated insects. Can. Dept. Agr., Tech. Bull. 37 (NS).

\section{C.I.F. LAPEL PINS}

Official C.I.F. lapel pins are available to Institute Members. If you wish one, place a check beside the type you want and forward your cheque or money order to:

Canadian Institute of Forestry

10 Manor Road West,

Toronto 7, Ontario.

Sterling Silver enamelled at $\$ 2.00$

Sterling Gilt enamelled at $\$ 2.50$

$10 \mathrm{~K}$ Gold enamelled at $\$ 6.00$ 